\title{
Devonian Tentaculitoidea of the Malvinokaffric Realm of Brazil, Paraná Basin
}

\author{
Jeanninny Carla Comniskey and Renato Pirani Ghilardi
}

\begin{abstract}
The Tentaculitoidea is represented by extinct invertebrates characterized by small, conic, carbonate shells of animals that inhabiting exclusively marine environments. The tentaculitoids occur from the Ordovician to Devonian, with diversity peaking in the Middle Devonian. The Tentaculitoidea has three orders: Tentaculitida (benthic habit), Homoctenida, and Dacryoconarida (planktonic habit). In Brazil, the oldest tentaculitoids occur in strata of the early Silurian, with the genus Tentaculites. Specimens of the Dacryoconarida and Homoctenida orders were only found in the Lower Devonian strata. In this study, we conducted taxonomic analyses of specimens in collections from various research institutions, including samples used in the last systematic study with this group, in mid-1991. The present study aims to review the systematic aspects of the tentaculitoids of the Devonian strata, Paraná basin, Brazil. Seven species of tentaculitoids were identified: two species previously described, Tentaculites jaculus and Tentaculites crotalinus and five news species: Tentaculites kozlowskii, Tentaculites paranaensis, Uniconus ciguelii, Homoctenus katzerii, and Styliolina langenii. This is the first known occurrence of the genus Uniconus in Devonian strata from Brazil. The analyzed species of homoctenids and dacryoconarids are larger than those previously described in the specialized literature. This study demonstrated that the tentaculitoids of the Paraná Basin have a stratigraphic distribution from the end of the Pragian to the early Givetian.
\end{abstract}

Jeanninny Carla Comniskey. Faculdade de Filosofia, Ciências e Letras de Ribeirão Preto, Pós-Graduação em Biologia Comparada, Universidade de São Paulo-USP. Av. Bandeirantes, 3900. CEP 14040-901 Bairro Monte Alegre - Ribeirão Preto - SP, Brazil. comniskey@gmail.com

Renato Pirani Ghilardi. Faculdade de Ciências. Departamento de Ciências Biológicas. Universidade Estadual Paulista-UNESP. Av. Eng Luiz Edmundo Carrijo Coube, 14-01. CEP 17033-360. Bauru-SP, Brazil.ghilardi@fc.unesp.br

Keywords: Systematics; Class Tentaculitoidea; Devonian; Brazil; Apucarana Sub-basin; new species

Submission: 17 August 2016 Acceptance: 30 May 2018

http://zoobank.org/AC834A01-9EF3-4BB6-B4D5-C6D810B784D8

Comniskey, Jeanninny Carla and Ghilardi, Renato Pirani. 2018. Devonian Tentaculitoidea of the Malvinokaffric Realm of Brazil, Paraná Basin. Palaeontologia Electronica 21.2.21A 1-14. https://doi.org/10.26879/712 https://palaeo-electronica.org/content/2018/2230-tentaculitoids-of-brazil

Copyright: June 2018 Palaeontological Association.

This is an open access article distributed under the terms of the Creative Commons Attribution License, which permits unrestricted use, distribution, and reproduction in any medium, provided the original author and source are credited.

creativecommons.org/licenses/by/4.0/ 


\section{INTRODUCTION}

The systematics of tentaculitoids is still subject of intense debates (Farsan, 1984, 1994, 2005; Wittmer and Miller, 2011; Schindler, 2012; Wei et al., 2012). Considering that this is an extinct group, the classification is exclusively based on morphology and shell ornamentation of preserved pieces (Azevedo-Soares, 1999). Tentaculitoidea has been placed among various invertebrate groups. Bouček (1964) and Farsan (1994) claimed that this class has greater biological similarities to the phylum Mollusca. However, recent studies have identified similarities with microconchids (Weedon, 1991; Vinn and Taylor, 2007; Vinn and Mutvei, 2009; Zatoń and Taylor, 2009; Vinn, 2010, 2013; Vinn and Zatoń, 2012).

Tentaculitoids belong to the class Tentaculitoidea Lyashenko, 1955 (= Cricoconarida Fisher, 1962) and correspond to a group of animals bearing conical shells ranging in length from millimeters to centimeters (Clarke, 1913; Ciguel, 1989; Azevedo-Soares, 1999; Comniskey and Ghilardi, 2013; Comniskey, 2016). Most of the specimens exhibit a straight shell, but they can have curved or coiled shells (Alberti, 1987, 1993, 1997, 1999, 2000; Larsson, 1979; Koren et al., 2007; Schindler, 2012).

The class Tentaculitoidea is divided into three orders (Figure 1): Tentaculitida Lyashenko, 1955, Homoctenida Bouček, 1964, and Dacryoconarida Fisher, 1962. Members of the order Tentaculitida have calcite shells with thick walls, lengths of 1-80 $\mathrm{mm}$ and widths up to $6 \mathrm{~mm}$. They are ornamented with rounded rings of different shapes and sizes. In some cases, they have macrorings with annulets (Fisher, 1962; Lardeux, 1969; Larsson, 1979). The Dacryoconarida are usually small (8-18 $\mathrm{mm}$ ), exhibiting a thin-walled shell and a bulbous apex. Shell ornamentation may be present, and in some cases, irregular growth lines may develop (Fisher, 1962; Lardeux, 1969). The Homoctenida are small (8-15 mm), also displaying thin-walled shells with a narrow cone shape. They are lightly curved, rarely straight, and sometimes resemble a series of cones with thin walls (Fisher, 1962; Wittmer and Miller, 2011; Schindler, 2012). The ornamentation consists of often numerous rings with angular profiles, all similar to each other or differing in size and concave interspaces (Lardeux, 1969). They are different from the Tentaculitida in having prominent ornamentation (e.g., macrorings), which is repeated on the inner wall of the shell. The orders Homoctenida and Dacryoconarida are considered to be planktonic, whereas the Tentaculitida are

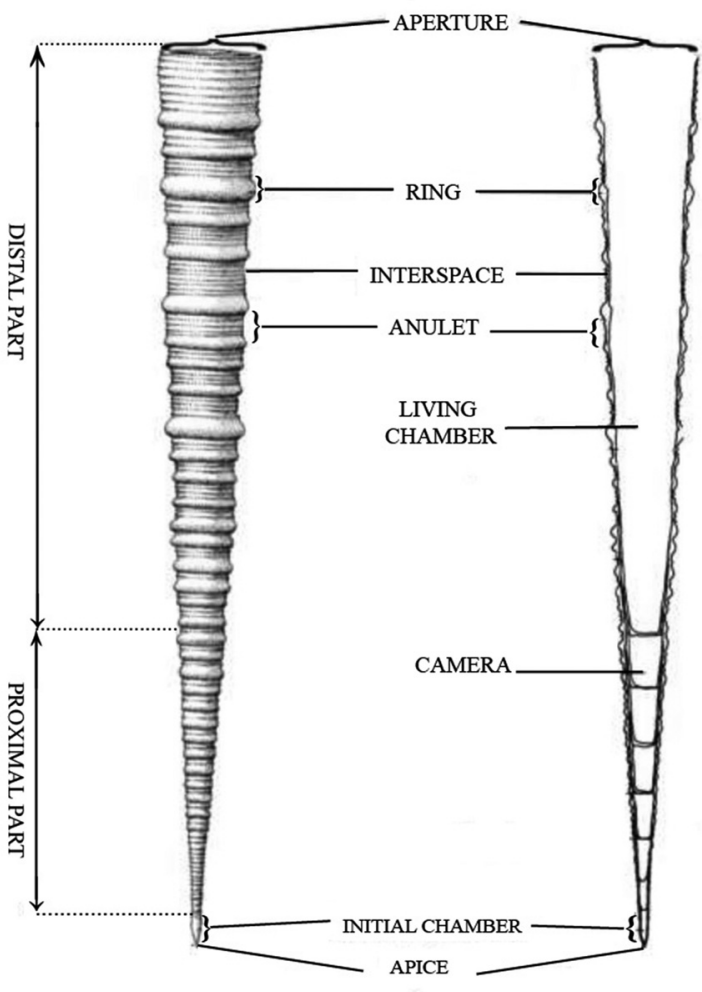

FIGURE 1. Morphological parts of a tentaculitoid shell (adapted from Larsson, 1979).

considered benthonic (Wittmer and Miller, 2011; Schindler, 2012).

There are few papers that report the occurrence of tentaculitoids from the Silurian of South America (Clarke, 1899b; Isaacson et al., 1976; Boucot et al., 1980; Ciguel, 1988, 1989; Grahn, 1992; Heredia et al., 2007; Malanca et al., 2010). Therefore, it is the Devonian specimens that increase the taxonomic studies of this group (Hartt and Rathbun, 1875; Derby, 1890; Ulrich, 1893; von Ammon, 1893; Katzer, 1897, 1903, 1933; Kayser, 1897, 1900; Siemiradzki, 1898; Clarke, 1899a, 1913; Schuchert, 1906; Knod, 1908; Boucot et al., 1980; Ciguel et al., 1984, 1987; Ciguel and Rosler, 1985; Ciguel, 1988, 1989).

In Brazil, there are few tentaculitoid taxa reported throughout the entirety of the Paleozoic (Hartt and Rathbun, 1875; Clarke, 1899a, 1913; Melo, 1985; Ciguel, 1989; Azevedo-Soares, 1999; Comniskey and Ghilardi, 2013; Comniskey et al., 2015). The pioneering studies of Hartt and Rathbun (1875) described the first tentaculitoid species, Tentaculites eldredgianus from the Amazon Basin. Later, Katzer (1897) listed the Devonian fauna of the Amazon Basin, where they recorded the Ten- 
taculites crotalinus (Salter, 1856) species, originally described in Devonian strata of South Africa. Katzer (1897) also made the first mention of the genus Styliolina from the Devonian in Brazil. Clarke (1899a, b, 1913) contributed to the description of the new tentaculitoid species, Tentaculites stubeli and T. trombetensis (Amazon Basin), T. oseryi (Parnaíba Basin) and T. jaculus (Paraná Basin). The studies conducted by José Henrique Godoy Ciguel in early 1980s represented a great advancement in the knowledge of tentaculitoids in Brazil. The author described numerous species of the tentaculitoids, but only in his unpublished thesis, which is not in accordance with the standards of the International Code of Zoological Nomenclature (ICZN). Thus, the species described by Ciguel have no validity. Azevedo-Soares (1999) also analyzed the tentaculitoids of the Paraná Basin, identifying two species: $T$. crotalinus and $T$. jaculus.

After a detailed bibliographic revision on the Devonian tentaculitoids from Brazil, the scarcity of systematic information and accurate species descriptions was clear. For this reason, we present a systematic review in order to resolve the taxonomic questions of this group in the Devonian of the Paraná Basin, Brazil.

\section{MATERIAL AND METHODS}

Several visits to scientific collections of universities, museums, and Brazilian research institutions were conducted. Approximately 800 samples were analyzed in the following scientific collections: Núcleo de estudos paleontológicos da Universidade Estadual do Rio de Janeiro (UERJ), Laboratório de Paleontologia de Invertebrados do Museu Nacional (MN), Laboratório de Paleontologia da Universidade Federal do Paraná (UFPR), Laboratório de Paleontologia e Sistemática do Instituto de Geociências da Universidade de São Paulo (IGc - USP), Departamento Nacional de Produção Mineral (DNPM), Laboratório de Estratigrafia e Paleontologia da Universidade Estadual de Ponta Grossa (UEPG), and Laboratório de Paleontologia de Macroinvertebrados da Universidade Estadual Paulista (UNESP-Bauru). In addition to those visits, new samples were collected in classic outcrops to increase the number of analyzed specimens.

The first analysis revealed that some of the species proposed by Ciguel (1989) are taphotaxa. This term was proposed by Lucas (2001) and is here used to refer a taxon with a distinct morphology that does not reflect taxonomic aspects, but rather taphonomic process that changed the original morphology (Lucas, 2001). Therefore, several taxa were synonymized.

\section{GEOLOGY OF THE STUDY AREA}

The Paraná Basin (Figure 2) is an intracratonic, intercontinental and polycyclic sedimentary basin. It covers an area of $1,700,000 \mathrm{~km}^{2}$ (Milani et al., 2007). This basin had two depocenters, the Alto-Garças Sub-Basin (north) and the Apucarana Sub-Basin (south). Milani et al. (2007) recognized six major sequences that represent depositional periods of a few million years. The Paraná supersequence (Devonian) is the second and is represented by successive transgressive-regressive cycles that are linked to sea-level oscillations (Milani et al., 2007). The studied outcrops are part of the Campos-Gerais Group (sensu Grahn et al., 2000, 2013; Gaugris and Grahn, 2006; Mendlowicz Mauller et al., 2009). The Furnas, Ponta Grossa, and São Domingos (including the Tibagi Member) formations compose the Campos-Gerais Group in ascending order (for synthesis, see Grahn et al., 2013). A regional gap is recorded during the latest early Emsian and the earliest late Emsian, as a result of the Andean Pre-Cordillera epirogenesis (Grahn et al., 2013).

The analyzed fossils derive from outcrops of the Ponta Grossa and São Domingos formations. The Ponta Grossa Formation is composed of black shales, light-gray, dark mudstones, massive to laminated siltstones and interspersed sandy layers with wave or hummocky cross-stratification (Grahn et al., 2013), and trace fossils mainly representing the Cruziana ichnofacies (Sedorko et al., 2018). This unit is characterized by marine deposits of shoreface to offshore environments, in a dominantly transgressive trend (Bergamaschi, 1999; Horodyski et al., 2014). According to Grahn (1992), Gaugris and Grahn (2006) and Grahn et al., (2000 2010, 2013), this formation ranges from the early Pragian to the late Emsian. The São Domingos Formation consists of mudstones, shales, siltstones, sandstones, and conglomeratic sandstones (Grahn et al., 2013). The main sedimentary structures are planar lamination, wave ripples, flaser bedding, and hummocky cross-stratification, and trace fossils (mainly representing proximal suites of the Cruziana ichnofacies). These strata represent marine deposits of the inner and outer shelf. According to Grahn et al., (2013) the age span is Emsian to Frasnian. 


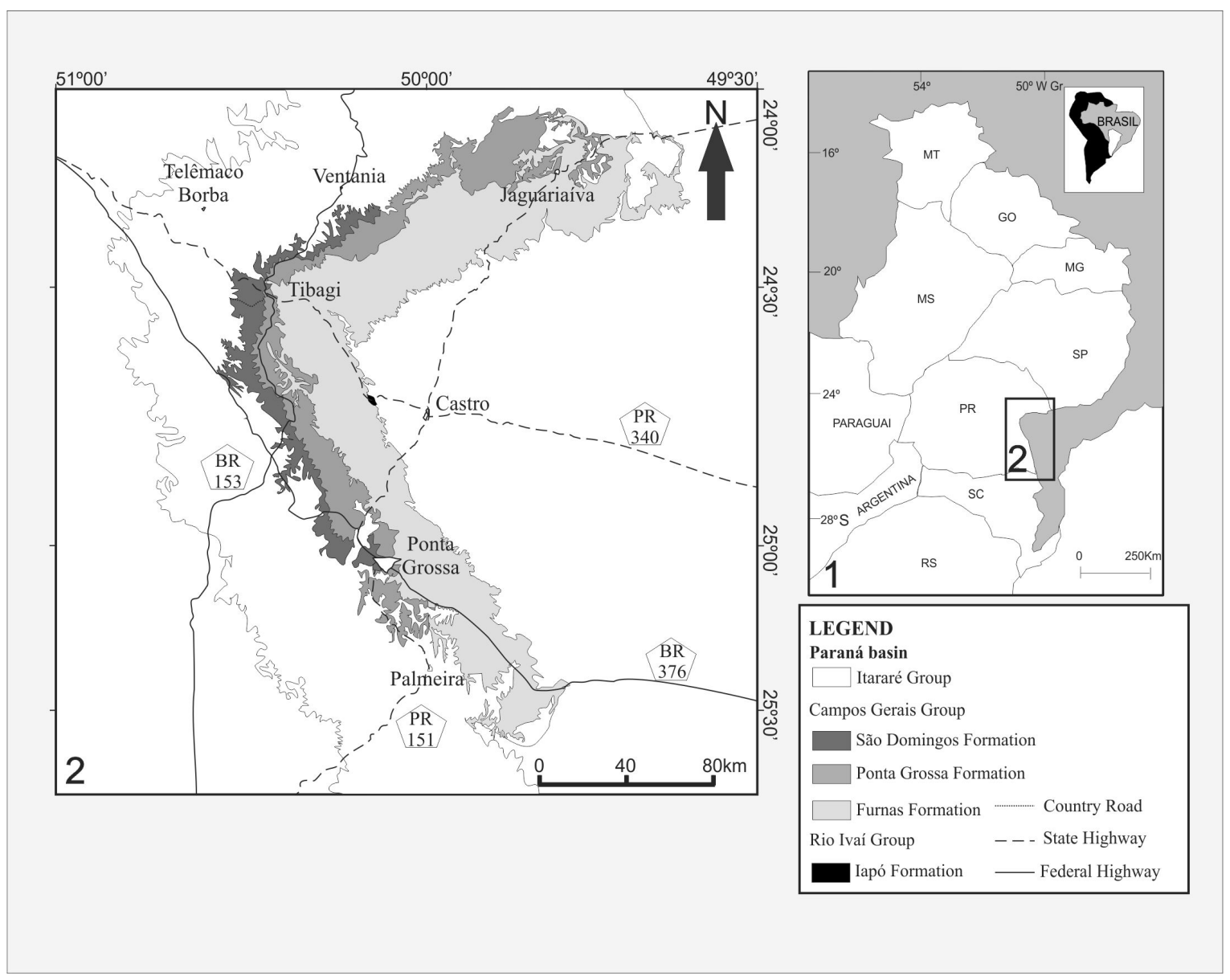

FIGURE 2. Geological map of the analyzed area, showing the region where specimens were collected in 1 , and the geological formations of the region in 2 (adapted from Bosetti et al., 2010).

\section{SYSTEMATIC PALEONTOLOGY}

Class TENTACULITOIDEA Lyashenko, 1957 Order TENTACULITIDA Lyashenko, 1955

Family TENTACULITIDAE Walcott, 1886

Genus TENTACULITES von Schlotheim, 1820

Diagnosis (from von Schlotheim, emended). Medium to large (10-40 mm), conical shell, with the proximal part expanding at 6-13 degrees and distal part at 1-50 degrees, or becoming subcylindrical. This genus of the family Tentaculitidae displays a straight conch but the proximal part can be curved. Initial chamber conical is gradual in the juvenile part. Width of the distal conch is $1.5-2 \mathrm{~mm}$, and occasionally up to $3 \mathrm{~mm}$. The exterior part presents prominent primary rings perpendicular to oblique in relation to the long axis and distal slopes of rings. The interior of the conch is divided proximally by septa, in the most proximal part they are mostly free, and in the distal part they are endoconic. Occasionally, all endoconic septa are densely packed. The living chamber is long, with a conical or subcylindrical shape and distinctly conical proximal termination. The internal wall surface is clearly undulating along most of the living chamber because of well-developed annular shelves in the rings, distal to their crests. Pseudopuncta may be present.

Type species. Tentaculites scalaris von Schlotheim, 1820.

Age. Species from the Silurian, Oberwiederstädt, Germany.

Tentaculites paranaensis $\mathrm{n}$. $\mathrm{sp}$.

Figure 3.1-3, 3.5, 3.8-9

zoobank.org/01C561A4-FB1C-4CD1-9955-99161A3B5B51

Diagnosis. Large and conical shells $(10-28 \mathrm{~mm})$. Annulations have different sizes in the juvenile and aperture region. Robust rings are present and interspaces are wide and shallow. In some cases, annulets are present in the adult region and aperture. Embryonic chamber is pointed.

Comparison. Tentaculites paranaensis sp. nov. differs from $T$. crotalinus, $T$. jaculus and $T$. kozlows- 


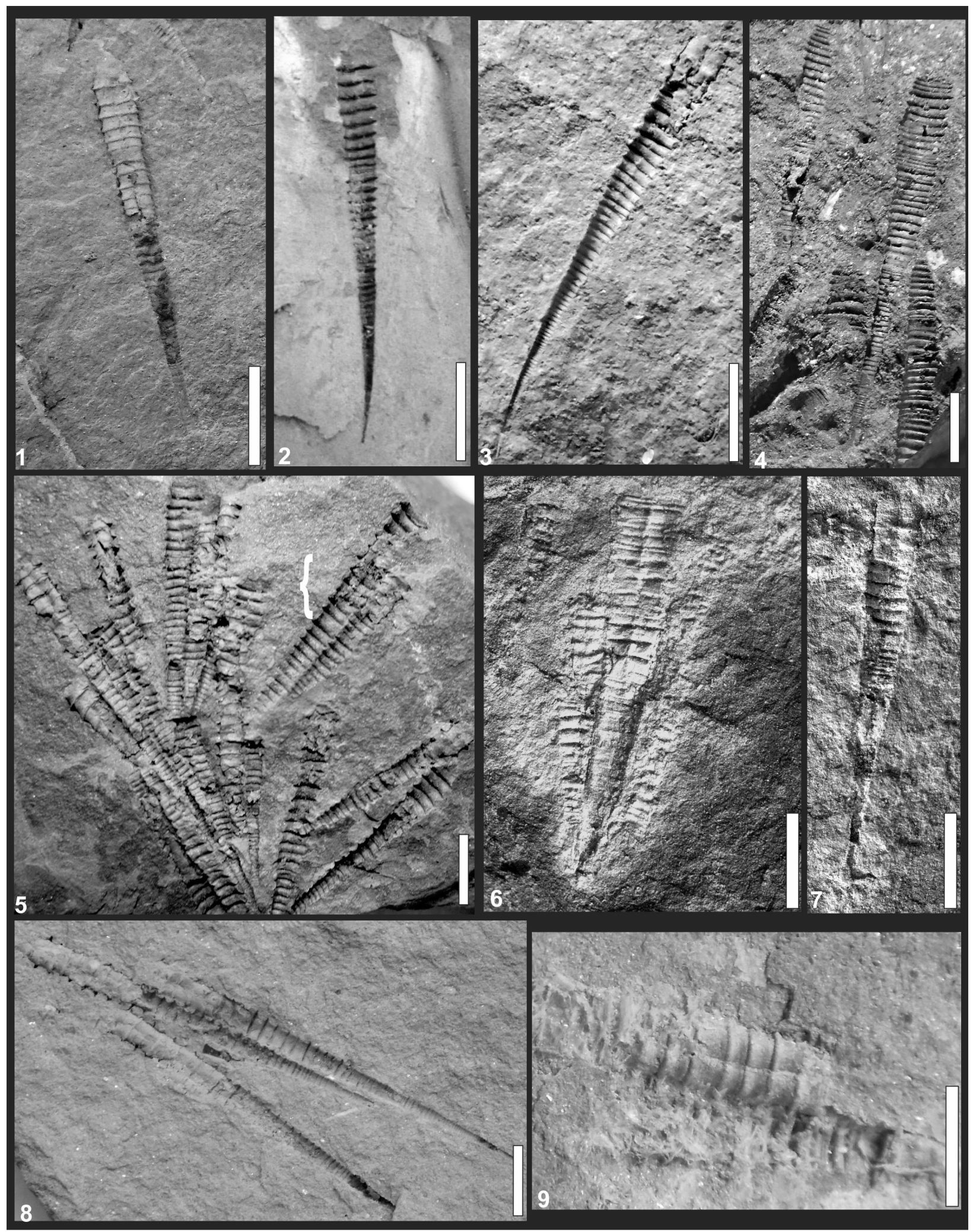

FIGURE 3. Tentaculites paranaensis. 3.1 paratype, 3.2 holotype (NR 4784, GP/1E 3242, respectively), 3.3 shows apical region slightly curved (NR 7137), 3.5 groupings of $T$. paranaensis (Unirio 89 ten), 3.8 (NR 5466), 3.9 shows the thin and inexpressive rings (NR 6515). Tentaculites kozlowskii. 3.4, 3.6 paratype, 3.7 holotype (MN 7030, MPI 9832, MPI 9837, respectively). Scale $0.5 \mathrm{~cm}$. 
kii by the presence of regularly arranged rings and wider interspaces. It differs from $T$. crotalinus by its large shell size and from $T$. jaculus by the presence of rings in the juvenile region and with wider interspaces. Finally, T. paranaensis differs from $T$. kozlowskii due to larger rounded rings and slightly curved embryonic chamber.

Etymology. Tribute to Devonian fossils found in the Paraná basin, Paraná, Brazil.

\section{Material}

Type material. Holotype: GP/1E 3242; type locality: Paraná State, Brazil. Ponta Grossa Formation; age: Late Pragian to late Emsian.

Paratypes. Igc 1/E 3414; Igc 1/E 1296; Igc 1/E 3247 (deposited in Instituto de Geociências da Universidade de São Paulo, Igc-USP); NR 4784; NR 6115; and NR 7458 (deposited in Universidade Federal do Paraná, UFPR).

Total number of specimens. 24.

Dimensions (Table 1). Length of the shell ranges from 10 to $28 \mathrm{~mm}$. Approximately 8-10 rings per 5 $\mathrm{mm}$. The growth angle varies between 3 and 6 degrees.

Description. Shells are ornamented with angular discoid rings that are slightly protruding, relatively thin, and symmetrical. The rings increase in size from the juvenile region to the aperture region, with little difference between the proximal and distal parts. Additionally, the interspaces homogeneously increase in size from the proximal region to the distal region. The interspaces are gently concave (in rare exceptions, the interspaces are deeply concave). Annulets occur in some specimens; if present, they are located in the aperture region and characterized by thin and weakly developed microstructures. The embryonic chamber is pointed to rounded.

Tentaculites kozlowskii n. sp.

Figure 3.4, 3.6-7

zoobank.org/13A218DC-36B5-4892-9CEB-46C3310928F7

Diagnosis. Conical, rounded, discoid, prominent shell, presenting thick rings of various sizes. Interspaces are deeply concave, and irregularly distributed. Annulets are not common, but when present are irregularly distributed in the aperture and adult regions. The apex is conical and weakly annulated. Embryonic chamber is pointed.

Comparison. Tentaculites kozlowskii is characterized by the presence of thick and prominent rings and concave interspaces with irregular distances. This species differs from $T$. crotalinus and $T$. jaculus by the arrangement of the rings; in T. crotalinus, rings gradually increase in size from the juvenile region to the aperture region, whereas in $T$. jaculus, only the adult region has rings. The embryonic chamber of $T$. kozlowskii is slightly more rounded than in T. jaculus.

Etymology. Tribute to Roman Kozlowski, a Polish researcher who studied the Devonian fossils from the Parana Basin, in 1913.

\section{Material}

Type material. Holotype: MPI 9837 deposited in the Laboratório de Estratigrafia e Paleontologia, Universidade Estadual de Ponta Grossa (UEPG), type locality: Tibagi, Ponta Grossa Formation; age: Late Pragian to late Emsian.

Paratypes. MPI 2077; MPI 9832 (deposited in the Laboratório de Estratigrafia e Paleontologia, Universidade Estadual de Ponta Grossa (UEPG); GP 1/E 1285 (deposited in Instituto de Geociências da Universidade de São Paulo, Igc-USP); and CCLP 52 (deposited in Laboratório de Paleontologia de Macroinvertebrados, UNESP).

Total number of specimens. 11

Dimensions (Table 1). Length ranges from 6 to 12 $\mathrm{mm}$. Eight to 11 rings per $5 \mathrm{~mm}$. Growth angle varies between 7 and 8 degrees.

Description. Shell is conical and ornamented with rounded discoid, and slightly prominent rings. The thickness of the rings increase from the juvenile region to the aperture region. In some specimens, the interspaces of the juvenile portion are much smaller than the interspaces of the adult portion. In the adult region, the interspaces can be twice as wide as the rings. Interspaces are flat to slightly concave. Annulets are rare; if present, they occur in the adult and aperture region. The apical region is usually ringed.

Family UNICONIDAE Lyashenko, 1955

Genus UNICONUS Lyashenko, 1955

Diagnosis (from Lyashenko, 1955). Small conical shell with exterior covered by angulate asymmetrical rings increasing in size and spacing toward aperture. Steeper part occurs in aperture side and the juvenile portion is septate. Growth angle is 7 to 9 degrees in juvenile portion and 4 to 6 degrees in mature portion.

Type species. Tentaculites glaber Trautschold, 1881.

Age. Late Ordovician, Silurian to Upper Devonian.

Uniconus ciguelii $\mathrm{n}$. $\mathrm{sp}$.

Figure 4.4, 4.7-8

zoobank.org/E2411A01-3C96-41B8-A08C-98BAD375ACCB

Diagnosis. Shell is conical and ornamented. Rings are prominent, thin, angular, asymmetrical, and 
TABLE 1. Comparison between tentaculitoids species analyzed ( $L=$ length of the shell, $W=$ width of the tube, $D R=$ diagonal rings).

\begin{tabular}{lcccc}
\hline & $\begin{array}{c}\mathbf{L} \\
\mathbf{( c m )}\end{array}$ & $\begin{array}{c}\text { W } \\
(\mathbf{c m})\end{array}$ & $\begin{array}{c}\text { DR } \\
\text { (per 0,5 cm) }\end{array}$ & $\begin{array}{c}\text { Apical angle } \\
\text { (degrees) }\end{array}$ \\
\hline Tentaculites crotalinus (Salter, 1856) & $0.9-2.5$ & $0.14-0.22$ & $4-8$ & $3-7^{\circ}$ \\
Tentaculites jaculus (Clarke, 1913) & $1.1-3.7$ & $0.23-0.46$ & $7-9$ & $8-9^{\circ}$ \\
Tentaculites paranaensis sp. nov. & $1-2.8$ & $0.15-0.3$ & $6-11$ & $3-6^{\circ}$ \\
Tentaculites kozlowskii sp. nov. & $0.6-1.2$ & $0.06-0.18$ & $13-16$ & $7-8^{\circ}$ \\
Uniconus ciguelii sp. nov. & $0.8-2.2$ & $0.15-0.21$ & $6-8$ & $3-8^{\circ}$ \\
Homoctenus katzerii sp. nov. & $0.8-1.5$ & $0.05-0.23$ & $6-14$ & $5-8^{\circ}$ \\
Styliolina langenii sp. nov. & $0.8-1.8$ & $0.12-0.3$ & - & $7-9^{\circ}$ \\
\hline
\end{tabular}

facing to the aperture. Interspaces are regular, smooth, shallow, weakly concave, and larger than rings. Annulets are present in some specimens. Embryonic chamber is pointed.

Comparison. The species has characteristics of Uniconus such as prominent asymmetrical rings facing the aperture that distinguish it from other genera. This is the first record of the genus from the Devonian of Brazil. The new species $U$. ciguelii differs from U. livnensis Lyashenko 1959 (see, Farsan, 1984, pg. 74, fig. 8 F-G) by the asymmetrical shape of the rings, larger and irregular interspaces and its longer shell.

Etymology. Tribute to José H.G. Ciguel, Brazilian researcher who raised the knowledge of tentaculitoids of the Brazilian Devonian.

Material

Type material. Holotype: CCLP 22, deposited in the Laboratório de Paleontologia de Macroinvertebrados da Universidade Estadual Paulista (UNESP); type locality: Jaguariaíva, Ponta Grossa Formation; age: Late Pragian - early Emsian.

Paratypes. CCLP 29; CCLP 39; CCLP 40 (deposited in the Laboratório de Paleontologia de Macroinvertebrados, UNESP) and DGM 1923 (deposited in Departamento Nacional de Produção Mineral, DNPM).

Total number of specimens. 17.

Dimensions (Table 1). They have approximate length of 8 to $22 \mathrm{~mm}$. Approximately 6-10 rings per $5 \mathrm{~mm}$. Growth angle is between 3 and 8 degrees.

Description. Conical ornamented shell with asymmetric angular rings. The last rings of the aperture region are pointed, facing up to a distal region. In some cases, it seems to be composed of successive cones fitted into each other. The rings are protruding, moderately thick, and the size of the rings increases gradually from the proximal to the distal region. The interspaces are gently concave to strongly concave, gradually increasing in size. In some samples, annulets can occur in the aperture region. The apex is ringed and the embryonic chamber is pointed only in a few specimens.

Order HOMOCTENIDA Bouček, 1964

Family HOMOCTENIDAE Lyashenko, 1955

Genus HOMOCTENUS Lyashenko, 1955

Diagnosis (from Lyashenko, 1955). Small conic shell with exterior covered by angulate rings, size and spacing of which increase proportionately toward aperture; concave interring areas wider than rings. Embryonic portion is conical and separated from rest of interior, with cavity usually presenting a single septum; however, 2 or 3 septa can be present. Transverse or longitudinal striae are absent. Growth angles are 9 to 15 degrees in juvenile portion and 6 to 12 degrees in mature portion.

Type species. Homoctenus krestovnikovi Lyashenko, 1955.

Age. Upper Devonian to early- middle Frasnian.

Homoctenus katzerii n. sp.

Figure 4.1-3

zoobank.org/3D212C6F-837A-47CD-9575-4684FC637C4D

Diagnosis. Shell is conical and ornamented; some specimens present a curved apical region. Rings are discoid, round, thick, slightly prominent, and symmetrical. The interannular space is highly concave. The interspace is larger in the aperture region when compared to the juvenile region. Annulets are located at the medial and aperture regions. Apex is weakly conical and annulated, and embryonic is rounded.

Comparison. Homoctenus differs from the other genera by being smaller and having rings and interspaces with similar and regular sizes. In Tentaculites and Uniconus, the size of the rings in the shell may vary. The species $H$. katzerensis and $H$. siemiradzkiensis informally proposed by Ciguel (1989) have similar specific diagnoses and most 


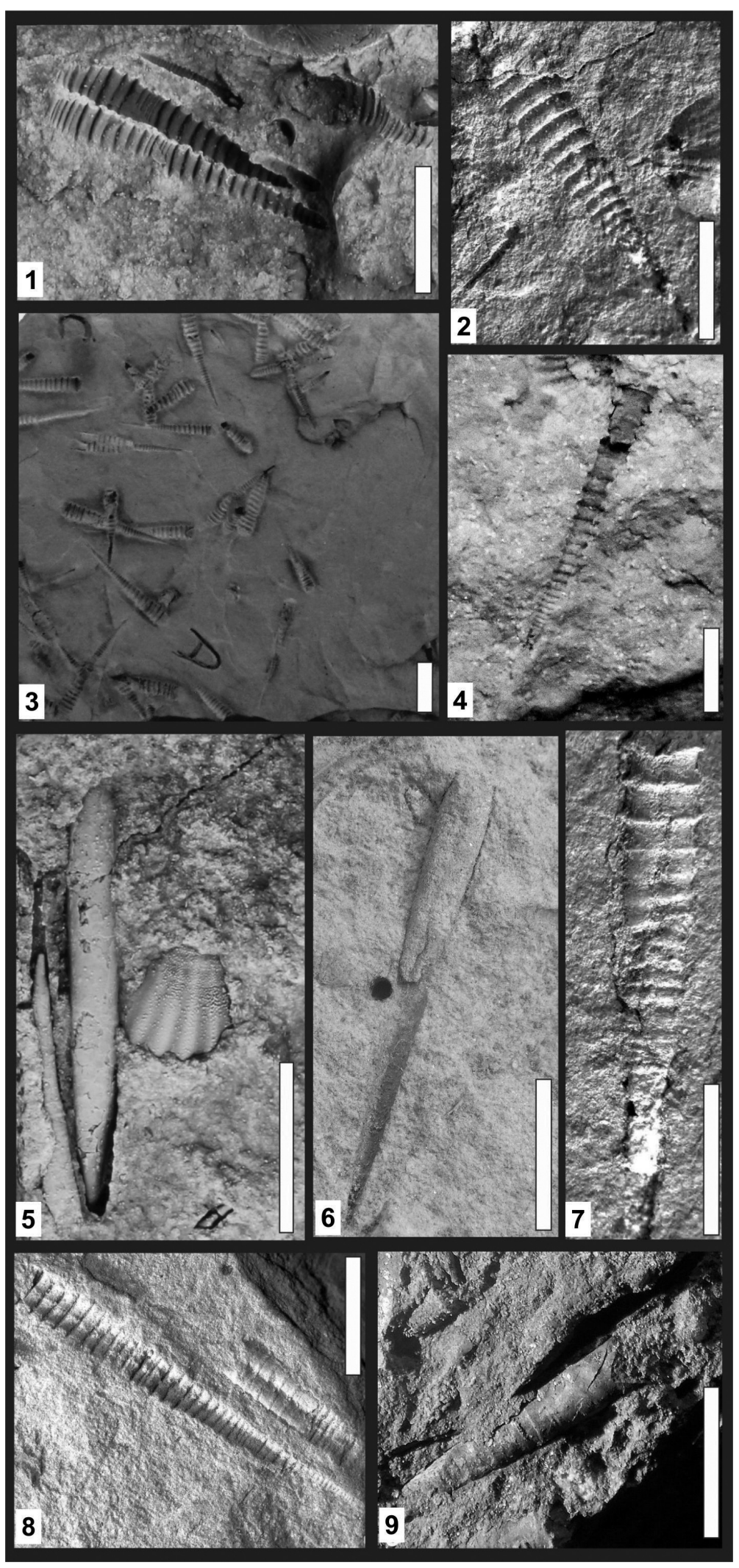

FIGURE 4. Homoctenus katzerii. 4.1 holotype, 4.2, 4.3 (MPI 907, CCLP 21, GP/ 1E 3637, respectively). Uniconus ciguelii. 4.4 holotype, 4.7, 4.8 (CCLP 22, CCLP 39, MPI 10152, respectively). Styliolina langenii. 4.5 holotype, 4.6, 4.9 (MPI 10152, DGM 1703, MN 7030). 
likely belong to the same species. Homoctenus katzerii differs from $\mathrm{H}$. krestovnikovi Lyashenko, 1957 (see, Lyashenko, 1957, p. 142, fig. 2 a-e) by length, more robust rings, smaller interspaces, and having rings up to the embryonic region.

Etymology. Homage to Friedrich Katzer, the researcher who published the first list of Devonian fossils of the State of Paraná in 1898.

\section{Material}

Type material. Holotype: MPI 907 deposited in Laboratório de Estratigrafia e Paleontologia, Universidade Estadual de Ponta Grossa (UEPG); type locality: Ponta Grossa, Ponta Grossa Formation; age: Late Pragian to late Emsian.

Paratype. GP 1/E 1294; GP 1/E 3633 (deposited in Instituto de Geociências da Universidade de São Paulo, Igc-USP); CCLP 10; CCLP 21; CCLP 25 (deposited in the Laboratório de Paleontologia de Macroinvertebrados, UNESP).

Total number of specimens. 23

Dimensions (Table 1). Shell 8 to $15 \mathrm{~mm}$ in length. Approximately 14 rings per $5 \mathrm{~mm}$. Growth angle between 5 to 8 degrees.

Description. Conical and ornamented shell presenting angular and thin rings, which gradually increase in size from the juvenile to aperture region. Interspaces are slightly concave, and present rings twice the size of the rings in adult and aperture regions. The annulets are found in some samples, located in the adult and in the aperture region in varied amounts. Some specimens presented a ringed shell from an apical region, which are thin and not expressive. The embryonic chamber is slightly abrupt and rounded.

Order DACRYOCONARIDA Fisher, 1962

Family STYLIOLINIDAE Grabau and Shimer, 1910 Genus STYLIOLINA Karpinsky, 1884

Diagnosis (from Karpinsky, 1884). The exterior is smooth except for scattered transverse striae; a pseudo-longitudinal groove is commonly present, but this results from crushing of the thin shell; molds of internal cavity look like exterior except that embryonic bulb is less teardrop-like and may even be conical. Growth angles are 8 to 14 degrees in juvenile region and 3 to 11 degrees in adult region.

Type species. Styliola nucleate Karpinsky, 1884. Age. Middle Silurian to Upper Devonian.

\section{Styliolina langenii $\mathrm{n} . \mathrm{sp}$.}

Figure 4.5-6, 4.9

zoobank.org/3B41AFDE-51D7-4559-A0B1-C3312F48DE60
Diagnosis. Conical, narrow, straight, unornamentad shell. Goticular embryonic chamber. The relatively thick-walled shell at the apex with 0.12-0.3 $\mathrm{cm}$ width. Growth angle varies between 5 and 13 degrees.

Comparison. Styliolina langenii has characteristics such as a smooth shell and teardrop-shaped embryonic chamber. These characters distinguish it from the other analyzed taxa. Compared to $S$. clavulus Barrande, 1867 it has a lower growth angle and a longer shell. Styliolina langenii possess a narrowly conical, straight shell, when compared to $S$. clavulus.

Etymology. Homage to Frederico Waldemar Lange for having contributed to the studies of paleontology of the Parana Basin region.

\section{Material}

Type material. Holotype: MPI 10152, deposited in Laboratório de Estratigrafia e Paleontologia, Universidade Estadual de Ponta Grossa (UEPG); type locality: Tibagi, Ponta Grossa Formation; age: Mid to late Emsian.

Paratype. MN 7430 (desposited in Museu Nacional-UFRJ); UNIRIO 22 ten, UNIRIO 16 ten (desposited in Universidade Federal do Rio de Janeiro (UNIRIO).

Total number of specimens. 22.

Dimensions (Table 1). Length varies from 8 to 18 $\mathrm{mm}$. Growth angle from 7 to 9 degrees.

Description. Surface of the shell is smooth. The species presents a narrow, straight, and conical shell. Growth lines are absent on the shells surface. The initial chamber is goticular.

\section{DISCUSSION AND CONCLUSIONS}

\section{Taxonomy}

After a detailed taxonomic review of approximately 800 samples, we verified the presence of seven species (of these, two were recognized from past research and five new species were described) of tentaculitoids for the Devonian of the Paraná Basin, Brazil. New samples found in collections, as well as the species described by Clarke (1913) and Ciguel (1989), were analyzed in the present study.

The species Tentaculites crotalinus and Tentaculites jaculus were previously recognized from the Devonian of the Paraná Basin (Clarke, 1913; Ciguel, 1989; Azevedo-Soares, 1999). After analyzing the species proposed by Ciguel (1989), it was verified that only three would be considered valid (Tentaculites koslowskiensis, Homoctenus 
katzerensis and Styliolina langensis); however, these species have never been formally published according to the rules of International Code of Zoological Nomenclature (ICZN). Thus, these taxa are here validated and three new species are named: Tentaculites kozlowskii, Tentaculites katzerii and Styliolina langenii. In addition, two new species are proposed: Tentaculites paranaensis and Uniconus ciguelii.

Therefore, the Brazilian Malvinokaffric in the Paraná Basin is composed of: Tentaculites crotalinus Salter, 1856, Tentaculites jaculus Clarke, 1913, Tentaculites kozlowskii, Tentaculites paranaensis, Uniconus ciguelii, Homoctenus katzerii, and Styliolina langenii.

\section{Stratigraphic Range}

The species Tentaculites crotalinus and Uniconus ciguelii occur between the late Pragian and early Emsian. Tentaculites jaculus, T. kozlowskii, T. paranaensis, and Homoctenus katzerii have stratigraphic distribution of the late Pragian to late Emsian. The species Styliolina langenii occurs only during the end of the Emsian (Figure 5). We decided to extend the distribution of the genus Homoctenus only from the end of the Pragian to the end of the Emsian; however, due to new occurrences of poorly preserved Homoctenus in outcrops from the lower Givetian, this group requires further analysis. All specimens found in Givetian black shales layers of the Paraná Basin are in outcrops deposited after the Kačák Crises (for more information see: Bosetti et al., 2011; Horodyski et al., 2014).

\section{Size}

Representatives of the genus Homoctenus and Styliolina presented a longer shell than other specimens already described for the Northern Hemisphere. Specimens of these orders usually exhibit a maximum length of $10 \mathrm{~mm}$. The studied homoctenids can reach 8 to $15 \mathrm{~mm}$ and dacryoconarids 8 to $18 \mathrm{~mm}$ in length. Ciguel et al. (1984) and Ciguel (1989) have also cited the occurrence of homoctenids and dacryoconarids with larger sizes than the Northern Hemisphere

Until now, it was known that representatives of Homoctenida and Dacryoconarida orders had maximum shell length of $10 \mathrm{~mm}$. The present authors, after analyzing dozens of samples, recog-

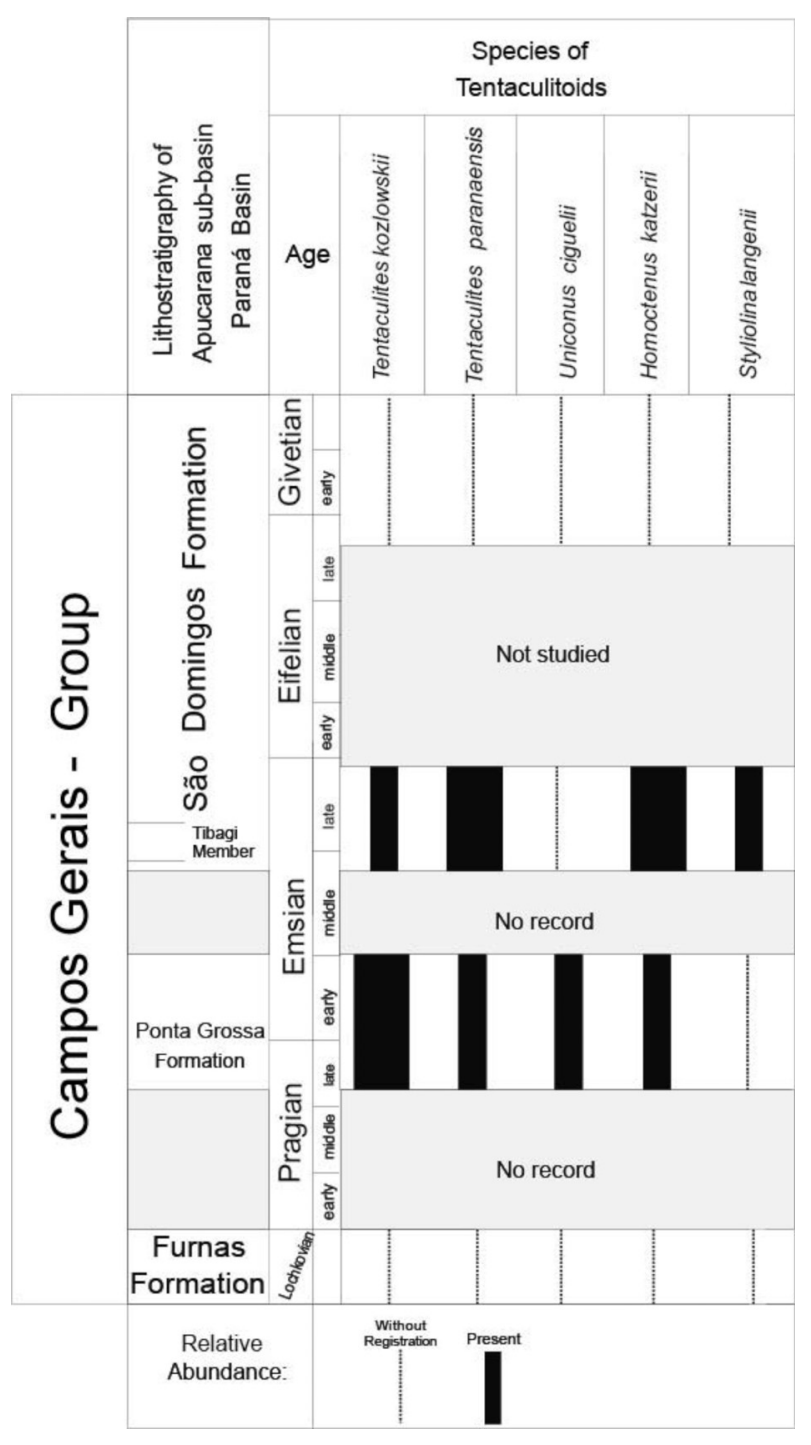

FIGURE 5. Biostratigraphic distribution of the new species of tentaculitoids in Devonian strata of the Paraná Basin.

nized the presence of homoctenids and dacryoconarids with larger sizes.

\section{ACKNOWLEDGMENTS}

Comniskey thanks the São Paulo Research Foundation (Fundação de Amparo à Pesquisa do Estado de São Paulo - FAPESP) for the doctoral scholarship granted (2013/04884-0). The authors thank the Brazilian educational and research institutions that enabled analyzing the studied material; E.P. Bosetti and his research group for their field support, extensive discussions, and suggestions 
regarding this manuscript; and $\mathrm{A}$. Clements for

English corrections in the final manuscript.

\section{REFERENCES}

Alberti, G.K.B. 1987. Zur paläobiogeographischen Verbreitung unter- und mitteldevonischer Dacryoconarida (Tentaculiten). Courier Forschungsinstitut Senckenberg, 92:161-176.

Alberti, G.K.B. 1993. Dacryoconariden und homocteniden Tentaculiten des Unter-und MittelDevons I. Courier Forschungsinstitut Senckenberg, 158:1-230.

Alberti, G.K.B. 1997. Planktonische Tentakuliten des Devon. II. Dacryoconarida Fisher 1962 aus dem Unter- und Mittel-Devon. Palaeontographica Abteilung A, 256:1-32.

Alberti, G.K.B. 1999. Homoctenus antecessor n. sp. (planktonische Tentaculiten, Homoctenida) aus der unteren Taravale-Formation (Unter-Zlichovium) von Victoria (Australien, Devon). Senckenbergiana lethaea, 79:297-300.

Alberti, G.K.B. 2000. Planktonische Tentakuliten des Devon. IV. Dacryoconarida FISHER 1962 aus dem Unter-Devon. Palaeontographica Abteilung A, 256:1-23.

Azevedo-Soares, H.L.C. 1999. Classe Tentaculita na Formação Ponta Grossa: uma proposta de sistematização. Unpublished Master's Thesis, Universidade do Estado do Rio de Janeiro, Rio de Janeiro, Brasil.

Barrande J. 1867. Système Silurien du centre de la Bohême, 1e partie, vol. 3. Ptéropodes. Chez l'auteur. Paris, Prague.

Bergamaschi, S. 1999. Análise estratigráfica do Siluro-Devoniano (Formações Furnas e Ponta Grossa) da sub-bacia de Apucarana, Bacia do Paraná, Brasil. Unpublished PhD Thesis, Universidade de São Paulo, São Paulo, Brasil.

Bosetti, E.P., Grahn, Y., Horodyski, R.S., Mauller, P.M., Breuer, P., and Zabini, C. 2011. An earliest Givetian "Lilliput Effect" in the Paraná Basin, and the collapse of the Malvinokaffric shelly fauna. Paläontologische Zeitschrift, 85:49-65. https://doi.org/10.1007/s12542-0100075-8

Bosetti, E.P., Horodyski, R.S., Zabini, C., Matsumura, W.M.K., and Godoy, L.C. 2010. Primeira ocorrência de Lingulepis (Brachiopoda-Obolidae) no Devoniano do estado do Paraná, Brasil. Boletim do Museu Paraense Emílio Goeldi Ciências Naturais, 5:151-164.

Bouček, B. 1964. The Tentaculites of Bohemia: their Morphology, Taxonomy, Ecology, Phylogeny and Biostratigraphy. Academy of Sciences of the Czech Republic, Prague.

Boucot, A.J., Isaacson, P.E., and Laubacher, G. 1980. An early Devonian, eastern Americas realm faunule from the coast of southern Peru. Journal of Paleontology, 54:359-365.

Ciguel, J.H.G. 1988. Tentaculites itacurubiensis n. sp., dos depósitos regressivos do Paraguai oriental, Siluriano Inferior da Bacia do Paraná. Revista Brasileira de Geociências, 18:86-92.

Ciguel, J.H.G. 1989. Bioestratigrafia dos Tentaculitoidea no flanco oriental da Bacia do Paraná e sua ocorrência na América do Sul. Unpublished Master's Thesis, Universidade de São Paulo, Instituto de Geociências, São Paulo, Brasil.

Ciguel, J.H.G. and Rosler, O. 1985. Caracterização das formas brasileiras de Tentaculites crotalinus Salter, 1856. Anais da Academia Brasileira de Ciências, 57:116.

Ciguel, J.H.G., Rosler, O., and Camineiro, D. 1984. Tentaculitoidea da formação Ponta Grossa no estado do Paraná. In Congresso Brasileiro de Geologia, 33, Rio de Janeiro. Anais. Rio de Janeiro: SBG, 655-669.

Ciguel, J.H.G., Rosler, O., and Hofmeister, R.M. 1987. Preservação parcial da concha de Tentaculites crotalinus, da Formação Ponta Grossa (Devoniano). Boletim lg-USP. Série Ciêntífica, 18:17-26.

Clarke, J.M. 1899a. Moluscos devonianos do Estado do Pará, Brasil. Archivos Museu Nacional, 10:49-174.

Clarke, J.M. 1899b. A fauna siluriana superior do Rio Trombetas. Archivos do Museu Nacional, 10:1-48.

Clarke, J.M. 1913. Fósseis Devonianos do Paraná. Monographias do Serviço Geológico e Mineralógico do Brasil, Rio de Janeiro.

Comniskey, J.C. 2016. Revisão sistemática, tafonomia, distribuição geográfica e estratigráfica da classe Tentaculitoidea no Devoniano brasileiro. Unpublished PhD Thesis, Universidade de São Paulo, Brasil. 
Comniskey, J.C. and Ghilardi, R.P. 2013. Levantamento histórico da Classe Tentaculitoidea no Devoniano brasileiro: principais características e padrões de preservação. Terr@ Plural, 7:115-126. https://doi.org/10.5212/TerraPlural.v.7iEspecial.0008

Comniskey, J.C., Ghilardi, R.P., and Bosetti, E.P. 2015. Conhecimento atual sobre os tentaculitoideos devonianos das bacias do Amazonas e Parnaíba, Brasil, depositados em instituições brasileiras. Boletim do Museu Paraense Emilio Goeldi, 10:49-61.

Derby, O.A. 1890. Nota sobre a geologia e paleontologia de Matto Grosso. Imprensa nacional, 5050.

Farsan, N.M. 1984. Die Tentakuliten aus dem Frasnium (Ober-Devon) von Ghuk (westliches Zentral-Afghanistan). Paläontologische Zeitschrift, 58:51-77.

Farsan, N.M. 1994. Tentaculiten: Ontogenese, Systematik, Phylogenese, Bioestratonomie und Morphologie. Abhandlungen der Senckenbergischen Naturforschenden Gesellschaft, 547:1128.

Farsan, N.M. 2005. Description of the early ontogenic part of the tentaculitids, with implications for classification. Lethaia, 38:255-270. https://doi.org/10.1080/00241160510013349

Fisher, D.W. 1962. Small connoidal shells of uncertain affinities. p. 98-130. In Moore, R.C. (ed.), Treatise on Invertebrate Paleontology, Part W, Miscellanea. Geological Society of America and University of Kansas Press, Boulder, Colorado, and Lawrence, Kansas, 1-250.

Gaugris, K.A. and Grahn, C.Y. 2006. New chitinozoan species from the Devonian of the Paraná Basin, south Brazil, and their biostratigraphic significance. Ameghiniana, 43:293-310.

Grabau, A.W. and Shimer, H.W. 1910. Cephalopoda in North American index fossils; invertebrates. AG Seiler, 2:16-233.

Grahn, C.Y. 1992. Revision of Silurian and Devonian strata of Brazil. Palynology, 16:35-61. https://doi.org/10.1080/01916122.1992.9989406

Grahn, C.Y., Mauller, P.M., Breuer, P., Bosetti, E.P., Bergamaschi, S., and Pereira, E. 2010. The Furnas/Ponta Grossa contact and the age of the lowermost Ponta Grossa Formation in the Apucarana Sub-basin (Paraná Basin, Brazil): integrated palynological age determination. Revista Brasileira de Paleontologia,13:89-102.

Grahn, C.Y., Mendlowicz Mauller, P., Bergamaschi, S., and Bosetti, E.P. 2013. Palynology and sequence stratigraphy of three Devonian rock units in the Apucarana Sub-basin (Paraná Basin, south Brazil): Additional data and correlation. Review of Palaeobotany and Palynology, 198:27-44. https://doi.org/10.1016/j.revpalbo.2011.10.006

Grahn, C.Y., Pereira, E., and Bergamaschi, S. 2000. Silurian and Lower Devonian chitinozoan biostratigraphy of the Paraná Basin in Brazil and Paraguay. Palynology, 24:143-172. https:// doi.org/10.1080/01916122.2000.9989542

Hartt, C.F. and Rathbun, R. 1875. Morgan expedition, 1870-1871: on the Devonian trilobites and mollusks of Erere, Province of Para, Brazil. Annals of the Lyceum of Natural History of New York, 11:110-127.

Heredia, S., Mestre, A., and Milana, J.P. 2007. Reappraisal of the Silurian stratigraphy at Cerro del Fuerte section (San Juan, Argentina). Anais do Congresso de Paleontología y Bioestratigrafía de Latinoamérica, 4:195-200.

Horodyski, R.S., Holz, M., Grahn, Y., and Bosetti, E.P. 2014. Remarks on sequence stratigraphy and taphonomy of the Malvinokaffric shelly fauna during the Kačák Event in the Apucarana Sub-basin (Paraná Basin), Brazil. International Journal of Earth Sciences, 103:367-380. https://doi.org/10.1007/s00531-013-0954-9

Isaacson, P.E., Antelo, B., and Boucot, A.J. 1976. Implications of a Llandovery (early Silurian) brachiopod fauna from Salta Province, Argentina. Journal of Paleontology, 50:1103-1112.

Karpinsky, A.P. 1884. Die fossilien Pteropoden am Osthabhange des Urals, 443-460. Akademiya Nauk Souza SSR (Reissued by Academy of Sciences of the USSR, Moscow and Leningrad, 1945.), 443-460.

Katzer, F. 1897. Das Amazonas-Devon und seine Beziehungen zu den anderen Devongebieten der Erde. Verlag der Königl. Böhmischen Gesellschaft der Wissenschaften, Prague.

Katzer, F. 1903. Grundzuge der Geologie des unteren Amazonasgebietes (dês Staates Pará in Brasilien). Max Weg, Leipzig.

Katzer, F. 1933. Geologia do Pará (Brasil). Boletim do Museu Paraense Emilio Goeldi, 9:1-270.

Kayser, E. 1897. Beiträge zur Kenntniss einiger paläozoischer Faunen Süd-Amerikas. Zeitschrift der Deutschen Geologischen Gesellschaft, 49:274-317.

Kayser, E. 1900. Alguns fósseis paleozóicos do Estado do Paraná. Revista do Museu Paulista, 4:301-311. 
Knod, R. 1908. Devonische faunen boliviens. Neues Jahrbuch für Geologie und Paläontologie Beilage, 25:493-601.

Koren, T.N., Kim, A.I., and Walliser, O.H. 2007. Contribution to the biostratigraphy around the Lochkovian-Pragian boundary in Central Asia (graptolites, tentaculites, conodonts). Senckenbergiana Lethaea, 87:187-219. https://doi.org/10.1007/BF03043914

Lardeux, H. 1969. Nouvelles données sur la morphologie des Tentaculitoidea. Éditions du Centre National de la Recherche Scientifique, 258:5939-5942.

Larsson, K. 1979. Silurian tentaculitids from Gotland and Scania. Fossils and Strata, 11:1-180.

Lucas, S.G. 2001. Taphotaxon. Lethaia, 34:30. https://doi.org/10.1080/ 002411601300068198

Lyashenko, G.P. 1955. Novye dannye o sistimatike tentakulitov, novakiyi I stiliolii. Biulleten Moskovskogo Obschestva Ispytatelei Prirody, Otdel Geologichskii, Novaia Seriia, 30: 94-95. (In Russian)

Lyashenko, G.P. 1957. New species from Middle Devonian tentaculites and styliolinids from the central part of the Russian Platform. Vnigni, 8:212-233. (In Russian)

Lyashenko, G.P. 1959. Devonian Conoconchia of the central and eastern parts of the Russian Platform. The All-Russian Research Institute of Oil, Moscow (VNIGN1). (In Russian)

Malanca, S., Aris, M.J., Boso, M.A., Gallardo, E., Brandán, E.M., and Fernández, J.C. 2010. Invertebrados fósiles de la formación Lipeón (Silúrico superior) del área Bermejo-los Toldos, noroeste argentino. Revista de La Asociacion Geológica Argentina, 66:171-177.

Melo, J.H.G. 1985. A Província Malvinocáfrica no Devoniano do Brasil. Unpublished Master's Thesis, Instituto de Geociências, Universidade Federal do Rio de Janeiro, Rio de Janeiro.

Milani, E.J., Melo, J.H.G., Souza, P.A., Fernandes, L.A., and França, A.B. 2007. Bacia do Paraná. Boletim de Geociências da Petrobrás, 15:265-287.

Mendlowicz Mauller, P., Grahn, C.Y., and Machado Cardoso, T.R. 2009. Palynostratigraphy from the Lower Devonian of the Paraná Basin, South Brazil, and a revision of contemporary Chitinozoan biozones from Western Gondwana. Stratigraphy, 6:313-332.

Salter, J.W. 1856. Description of Palaeozoic Crustacea and Radiata from South Africa. Geological Society of London Transactions, series 2, 7:215-224.

Schindler, E. 2012. Tentaculitoids - An Enigmatic Group of Palaeozoic Fossils, p. 470-490. In Talent, J.A. (ed.), Earth and Life: Global Biodiversity, Extinction Intervals and Biogeographic Perturbations Through Time. Springer, New York.

Schuchert, C. 1906. Geology of the Lower Amazon region. The Journal of Geology, 14:722-746.

Sedorko, D., Bosetti, E.P., and Netto, R.G. 2018. An integrative ichnological and taphonomic approach in a transgressive-regressive cycle: a case study from Devonian of Paraná Basin, Brazil. Lethaia, 51:15-34. https://doi.org/10.1111/let.12219

Siemiradzki, J. 1898. Geologische reisebeobachtungen in Südbrasilien. Aus Der KaiserlichKöniglichen Hof-und Staatsdruckerei, 107:23-40.

Trautschold, H.V. 1881. Uber Devonische Fossilien vom Schelonj. Bulletin de la Société des Naturalistes de Moscou, 56(1-2):432-440.

Ulrich, A. 1893. Palaeozoische Versteinerungen aus Bolivien. Neues Jahrbuch, Beil. Band, 8:6064.

Vinn, O. 2010. Adaptive strategies in the evolution of encrusting tentaculitoid tubeworms. Palaeogeography, Palaeoclimatology, Palaeoecology, 292:211-221. https://doi.org/10.1016/ j.palaeo.2010.03.046

Vinn, O. 2013. Cornulitid tubeworms from the Ordovician of eastern Baltic. Carnets de Geologie [Notebooks on Geology], 2013/03:1-6.

Vinn, O. and Mutvei, H. 2009. Calcareous tubeworms of the Phanerozoic. Estonian Journal of Earth Sciences, 58:286-296. https://doi.org/10.3176/earth.2009.4.07

Vinn, O. and Taylor, P.D. 2007. Microconchid tubeworms from the Jurassic of England and France. Acta Palaeontologica Polonica, 52:391-399.

Vinn, O. and Zatoń, M. 2012. Phenetic phylogenetics of tentaculitoids-extinct, problematic calcareous tube-forming organisms. GFF, 134:145-156. https://doi.org/10.1080/ 11035897.2012.669788

von Ammon, L. 1893. Devonische Versteinerungen von Lagoinha in Matto Grosso (Brasilien). Zeitschrift der Gesellschaft für Erdkunde zu Berlin, 28:352-366.

von Schlotheim, E.F. 1820. Die Petrefactenkunde auf ihrem jeztigen Stand- punkte durch die Beschreibung seiner Sammlung versteinerter und fossi- ler Überreste des Their-und Planzenreichs der Vorwelt erläutert. Gotha. 
Walcott, C.D. 1886. Studies on the Cambrian faunas of North America. United States Geological Survey, Bulletin, 30:1-225.

Weedon, M.J. 1991. Microstructure and affinity of the enigmatic Devonian tubular fossil Trypanopora. Lethaia, 24:227-234. https://doi.org/10.1111/j.1502-3931.1991.tb01471.x

Wei, F., Gong, Y., and Yang, H. 2012. Biogeography, ecology and extinction of Silurian and Devonian tentaculitoids. Palaeogeography, Palaeoclimatology, Palaeoecology, 358:40-50. https://doi.org/10.1016/j.palaeo.2012.07.019

Wittmer, J.M. and Miler, A. 2011. Dissecting the global diversity trajectory of an enigmatic group: The paleogeographic history of tentaculitoids. Palaeogeography, Palaeoclimatology, Palaeoecology, 312:54-65. https://doi.org/10.1016/j.palaeo.2011.09.009

Zatoń, M. and Taylor, P.D. 2009. Microconchids (Tentaculita) from the Middle Jurassic of Poland. Bulletin of Geosciences, 84:653-660. 